\title{
The Urgency of Social Potential Mapping of Women in The Coastal Area to Decrease Poverty
}

\author{
Mansyur Radjab ${ }^{1}$ Syamsuddin Simmau ${ }^{2}$ * \\ ${ }^{1}$ Dosen Sosiologi Fisip Universitas Hasanuddin, Makassar, Indonesia, email: radjabmansyur@gmail.com \\ ${ }^{2}$ Dosen Sosiologi Fisip Universitas Sawerigading, Makassar, Indonesia, email: symsuddinsimmau74@gmail.com
}

\section{A R T I C L E I N F O}

\section{How to Cite:}

Radjab, M., \& Simmau, S. (2019). The Urgency of Social Potential Mapping of Woman in The Coastal Area to Decrease Poverty. Hasanuddin Journal of Sociology (HJS), $1(1), 35-42$.

Keywords:

Social Mapping, Social Function, Poverty, Women In The Coastal

\begin{abstract}
A B S T RA C T
The result of this study is really meaningful to reduce the poverty of women who living in the coastal area. Poverty is the global issue that must be decreased sustainably until 2030 based on the United Nation Sustainable Development Goals (SDGs), especially for women living in the coastal area. The major objective of this study is to determine the social potential of women in the coastal area in order to reduce their poverty. The method used is mixed (quantitative and qualitative) method. There are 84 sample of this study. Data collected by using questioner and depth interview. The results of this study determined that the first important thing in reducing poverty of women in the coastal area is to map social potentials. The other urgent finding is lack of education, lack of skill, and women as unsupposed worker are the inhibiting factors of women to develop socially. On the other hand, the social potentials of women are; young worker, working time productivity, and the ownership of product. Therefore, the social potential mapping is the first important action to apply before empowering women in order to function a social function for reduction poverty.
\end{abstract}

(C) 2019 Hasanuddin Journal of Sociology. All rights reserved

\section{INTRODUCTION}

The poverty reduction is the global academic responsibility. There are 700 million living on less than $\$ 1.90$ a day, include Indonesia. Therefore, poverty is the global academic responsibility to end poverty by 2030 . The academic and education community have a major role in increasing the awareness about the impact of poverty. Science provides the foundation for new and sustainable approaches, solutions and technologies to tackle the challenges of reducing poverty and achieving sustainable development. The contribution of science to end poverty has been significant (UN). 
Poverty is a complex and multi-dimensional concept that characterized as the lack of basic need fulfillment such as; food, clothes and home; access on the other fundamental needs such as; education, health, sanitation, drinking water and transportation; lack of future security life, lack of human resources quality, lack of job access, and the marginalization because of disability (Suharto, 2010). A related issue shows that women as a social group is one of the marginal group (Soekanto, 2009). Therefore, women as a social group is categorized as poor group. This is supported by Mandel (1995). He said that women who working on agriculture, husbandry, manufacture, construction, and services companies are positioned as the marginal class worker. They had less salary then men. The fact argued by Henslin determined that if women as the chief of household, they would get a lower income than men, it is about $70 \%$ for women. These social conditions lied women on poverty over the lower middle-income countries, such as Indonesia.

In order to drive women out of poverty, Usman (2010) recommended 'women empowerment' and Suharto (2010) required 'social function'. Empowerment is a multi-process activities that support individual or social groups, community, society to have a powerful position to participate in any controls and influence on activities, programs, and social institution that influenced the live. Empowerment emphasizes that individual, or community or social group have a good skills, knowledge, and power to improve the quality of people life. Whereas, the social function is the ability of individual, family, group or society, social system in responding basics need fulfillment, facing conflict, and pressure.

But how can the women empowerment and social function be applied to drive women from poverty if there is no women social profile? Here is the urgency of social potential mapping. Netting (1993) exposed that social mapping is a systematic description of society, include social problem faced by the society. This is in order to recognize the person in-environment, history and development of society, and the change of society.

\section{METHOD}

The method used is mixed method (quantitative-qualitative). This study conducted on Sinjai and Bantaeng Regency, South Sulawesi Province, Indonesia, on November 2014. The sample of this study is 84 respondents. Respondents in Sinjai are fishermen's wife, whereas, in Bantaeng, they are seaweed farmers' wife. All of respondents are married. The data collected by questioner and depth interview. Data analyzed by using statistical analysis and qualitative analysis. 


\section{RESULTS}

\section{Inhibiting Factors of Women in Driving out of Poverty}

Based on data, there are three main factors inhabited women in the coastal area to drive out of poverty, they are; lack of education, lack of skill, and women as un-supposed worker. It is necessary to describe each factor.

In Bantaeng Regency, respondents are really on lowest education degree. Most of them graduated from secondary school. In Sinjai, either, most of respondents graduated from Secondary School and Junior Hight School. Table 1 below, show clearly the educational position of respondents.

Table 1. Formal Education of Respondents

\begin{tabular}{lrrr}
\hline $\begin{array}{c}\text { Highest Formal Education } \\
\text { of Respondents }\end{array}$ & Bantaeng & Sinjai & $\begin{array}{c}\text { Bantaeng+Sinj } \\
\text { ai }\end{array}$ \\
\hline Never/Have Not Studied & 6 & 1 & 7 \\
Secondary School & $14.3 \%$ & $2.4 \%$ & $8.3 \%$ \\
& 30 & 19 & 49 \\
Junior High School & $71.4 \%$ & $45.2 \%$ & $58.3 \%$ \\
& 6 & 13 & 19 \\
Senior High School & $14.3 \%$ & $31.0 \%$ & $22.6 \%$ \\
& 0 & 9 & 9 \\
\hline Total & $.0 \%$ & $21.4 \%$ & $10.7 \%$ \\
& 42 & 42 & 84 \\
& $100.0 \%$ & $100.0 \%$ & $100.0 \%$ \\
\hline
\end{tabular}

The other important inhibiting factors is the lack of skill. It is very clear that all of respondents in Bantaeng are working as households. In Sinjai, 95.2\% respondents are as housewife and only 2 (2.4\%) respondents are working in informal business sector.

Table 2: The Job of Respondents

\begin{tabular}{lrrr}
\hline \multicolumn{1}{c}{ Main Job } & Bantaeng & \multicolumn{1}{c}{ Sinjai } & $\begin{array}{c}\text { Bantaeng } \\
\text { +Sinjai }\end{array}$ \\
\hline Housewife & 42 & 40 & 82 \\
& $100.0 \%$ & $95.2 \%$ & $97.6 \%$ \\
Informal & 0 & 2 & 2 \\
Business & $.0 \%$ & $4.8 \%$ & $2.4 \%$ \\
\hline Total & 42 & 42 & 84 \\
& $100.0 \%$ & $100.0 \%$ & $100.0 \%$ \\
\hline
\end{tabular}

The other problem is the women worker in the coastal area are not really accepted as worker socially. Their position is second position after their husband. Therefore, they are un-supposed worker. They determine as husband assistants. Data shows that there are $20(47.6 \%)$ respondents do not have a 
secondary job and $16(38.1 \%)$ respondents help their husband. For very clear data, look at the following table.

Table 3. Respondents Secondary Job

\begin{tabular}{|c|c|c|c|}
\hline Secondary Jobs & Bantaeng & Sinjai & $\begin{array}{c}\text { Bantaeng+ } \\
\text { Sinjai }\end{array}$ \\
\hline \multirow[t]{2}{*}{ No Job } & 20 & 39 & 59 \\
\hline & $47.6 \%$ & $92.9 \%$ & $70.2 \%$ \\
\hline \multirow[t]{2}{*}{ Yielded of sea wood } & 4 & 0 & 4 \\
\hline & $9.5 \%$ & $.0 \%$ & $4.8 \%$ \\
\hline \multirow[t]{2}{*}{ Help Husband } & 16 & 0 & 16 \\
\hline & $38.1 \%$ & $.0 \%$ & $19.0 \%$ \\
\hline \multirow[t]{2}{*}{ Small Business } & 0 & 1 & 1 \\
\hline & $.0 \%$ & $2.4 \%$ & $1.2 \%$ \\
\hline \multirow{2}{*}{ Fish Weigh } & 0 & 1 & 1 \\
\hline & $.0 \%$ & $2.4 \%$ & $1.2 \%$ \\
\hline \multirow[t]{2}{*}{ Tailor } & 0 & 1 & 1 \\
\hline & $.0 \%$ & $2.4 \%$ & $1.2 \%$ \\
\hline \multirow[t]{2}{*}{ Labor } & 2 & 0 & 2 \\
\hline & $4.8 \%$ & $.0 \%$ & $2.4 \%$ \\
\hline \multirow[t]{2}{*}{ Total } & 42 & 42 & 84 \\
\hline & $100.0 \%$ & $100.0 \%$ & $100.0 \%$ \\
\hline
\end{tabular}

\section{Supporting Factors of Women in Driving out of Poverty}

Based on data, women living on the coastal area have supporting factors in order to drive out of poverty. These factors are; women as a young worker, working time productivity, and the ownership of product marketing. Table 4 below clearly describes that respondents are young women. They are productive worker.

Table 4: The Age of Respondents

\begin{tabular}{crrr}
\hline Age & Bantaeng & Sinjai & $\begin{array}{c}\text { Bantaeng } \\
\text { +Sinjai }\end{array}$ \\
\hline $15-19$ & 2 & 0 & 2 \\
& $4.8 \%$ & $.0 \%$ & $2.4 \%$ \\
$20-24$ & 9 & 2 & 11 \\
& $21.4 \%$ & $4.8 \%$ & $13.1 \%$ \\
$25-29$ & 12 & 7 & 19 \\
& $28.6 \%$ & $16.7 \%$ & $22.6 \%$ \\
$30-34$ & 6 & 7 & 13 \\
$35-39$ & $14.3 \%$ & $16.7 \%$ & $15.5 \%$ \\
& 5 & 8 & 13 \\
& $11.9 \%$ & $19.0 \%$ & $15.5 \%$
\end{tabular}




\begin{tabular}{lrrr}
$40-44$ & 4 & 8 & 12 \\
& $9.5 \%$ & $19.0 \%$ & $14.3 \%$ \\
$45-49$ & 4 & 4 & 8 \\
& $9.5 \%$ & $9.5 \%$ & $9.5 \%$ \\
$50-54$ & 0 & 4 & 4 \\
& $.0 \%$ & $9.5 \%$ & $4.8 \%$ \\
$55-60$ & 0 & 2 & 2 \\
& $.0 \%$ & $4.8 \%$ & $2.4 \%$ \\
\hline Total & 42 & 42 & 84 \\
& $100.0 \%$ & $100.0 \%$ & $100.0 \%$ \\
\hline
\end{tabular}

The second supporting factors is the time of working. In Bantaeng, there are 28 (66.7\%) respondents working for 10 until 12 hours every day. In Sinjai, majority respondents are working between 4 until 9 hours every day. For clear description, look at the following table.

Table 5. Working Time Duration of Respondents

\begin{tabular}{|c|c|c|c|}
\hline Working Time & Bantaeng & Sinjai & $\begin{array}{c}\text { Bantaeng+ } \\
\text { Sinjai }\end{array}$ \\
\hline \multirow[t]{2}{*}{$4-6$ hours } & 0 & 16 & 16 \\
\hline & $.0 \%$ & $38.1 \%$ & $19.0 \%$ \\
\hline \multirow[t]{2}{*}{$7-9$ hours } & 10 & 16 & 26 \\
\hline & $23.8 \%$ & $38.1 \%$ & $31.0 \%$ \\
\hline \multirow{2}{*}{$10-12$ hours } & 28 & 8 & 36 \\
\hline & $66.7 \%$ & $19.0 \%$ & $42.9 \%$ \\
\hline \multirow[t]{2}{*}{$13-15$ hours } & 3 & 2 & 5 \\
\hline & $7.1 \%$ & $4.8 \%$ & $6.0 \%$ \\
\hline \multirow[t]{2}{*}{$16-18$ hours } & 1 & 0 & 1 \\
\hline & $2.4 \%$ & $.0 \%$ & $1.2 \%$ \\
\hline \multirow[t]{2}{*}{ Total } & 42 & 42 & 84 \\
\hline & $100.0 \%$ & $100.0 \%$ & $100.0 \%$ \\
\hline
\end{tabular}

The ownership of production marketing is the next supporting factor. It is important to describe that in Bantaeng, most of seaweed farmer production are owned by themselves, they are $33(78.6 \%)$ respondents. In contrary, in Sinjai, most of fishermen's production are owned by the capitalist. Most of production based on profit sharing, there are $27(64,3 \%)$ respondents for this. For clear information look at the following table:

\begin{tabular}{lrrr}
\hline \multicolumn{1}{c}{ Ownership of Product } & Bantaeng & Sinjai & $\begin{array}{c}\text { Bantaeng+ } \\
\text { Sinjai }\end{array}$ \\
\hline Farmers/Fishermen Owning & 33 & 15 & 48 \\
& $78.6 \%$ & $35.7 \%$ & $57.1 \%$ \\
Profit Sharing & 9 & 27 & 36 \\
& $21.4 \%$ & $64.3 \%$ & $42.9 \%$ \\
\hline
\end{tabular}




\begin{tabular}{lrrr}
\hline Total & 42 & 42 & 84 \\
& $100.0 \%$ & $100.0 \%$ & $100.0 \%$ \\
\hline
\end{tabular}

\section{DISCUSSION}

The lack of education is really lied women on the poverty. This condition, parallelly, caused women in unproductive workers. Hence, culturally, women positions are lower than their husband. In this case, women include as marginal groups, as Soekanto (2009) said. This is, then, driving women to the lack of skills. Finally, women forced on no-payment employers.

The lack of skills caused women become 'the non-identity worker'. Most of women in the coastal area are jobless because their main job as housewife is not recognized as a job social and culturally. This fact encounters the role theory on family that put women in domestic area, to service their husband, children and household, although, they are working along 12 hour in a day.

As the marginal class worker, women help their husband in a long process of production. Table 2 and 3 indicate that most of women are working as household and help their husband. It means that they characterized as no job women (jobless), although, in reality, they are hard workers. This is really a complex circle poverty of women life in the coastal area. Look at the figure below:

Figure 1. The Circle of Women Poverty in the Coastal Area

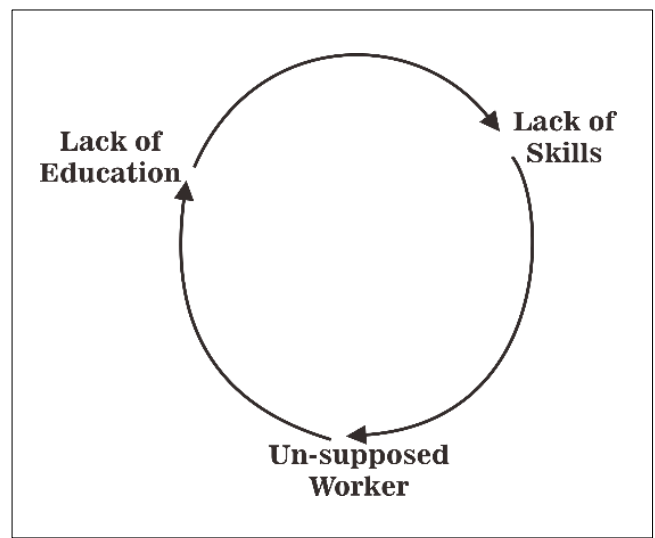

What has happened then? After applying social potential mapping, it could be determined that in order to carry women out of poverty, the empowerment and social function have to be intervened. It is important to note that the intervention is come from outsider. There are two targets of this intervention, they are women and social system. the circle on figure 1 changed to be the following figure: 
Figure 2. The Empowerment Intervention to the Circle of Women Poverty in the Coastal Area

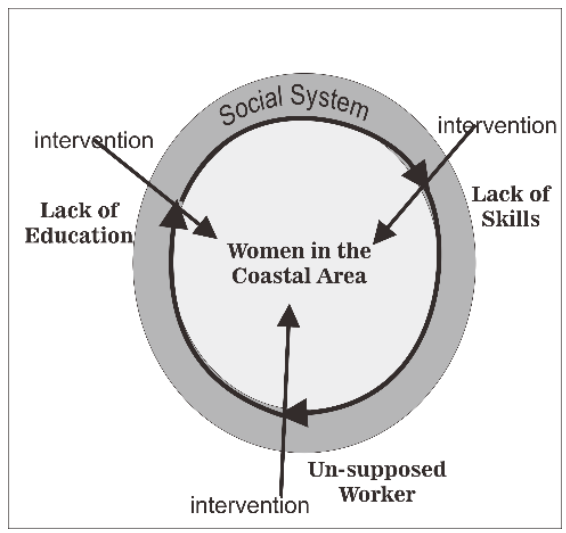

Empowerment intervention consists of strategic program, such as non-formal education to develop women cognitive knowledge, informal education to develop women skills. In the same time, the intervention programs to social systems are aimed to function the social function. Both empowerment and social function must be well and participative planning. So, the programs implementation would be on the tract, achieve the output and the outcome of each program. It is necessary to note that all of programs depended on the social potential mapping that ought to be ready before implementing the whole programs.

In this case, the social potential of women in the coastal area determined that women as a young worker, working time productivity, and the ownership of product marketing. Most of women here are in the productive age. They are working hard every day to manage their household and to help their husband. They also have access to decide where the product to market. These are really prospective potentials.

The outsider, must propose the program based on the social potentials of women according to their need, interest and resources. The results of these programs would be proposed to increase women consciousness and awareness that they have to act to develop their own selves. When the women consciousness and awareness become growing, on the same time, there would be appear the kind of consciousness and awareness from the women social environment as the impact of social system intervention program. Therefore, it more clear that, the social potential mapping is urgently required before doing empowerment and functioning the social function. 


\section{CONCLUTION}

Women in the coastal area bounded in the circle of poor women. The lack of education, lack of skill, and women as secondary worker have been the main factors of it. In order to overcome these problems, there must be two strategies; women empowering and social functioning for women. Before applying these strategies, the fist and main action program is mapping the social potentials of women.

\section{REFERENCES}

Boserup, Ester. 1984. Peranan Wanita dalam Pembangunan Ekonomi. Jakarta: Yayasan Obor Indonesia.

Henslin, Hourses M. 2007. Sosiologi dengan Pendekatan Membumi (Translated by Kamanto Sunato from Essential Sociology). Jakarta: Erlangga.

Ife, Jim and Frank Toseriero. 2008. Alternatif Pengembangan Masyarakat di Era Globalisasi Community Development (Translated by Sastrawan Manullang, Nurul Yakin, M. Nursyahid from Community Development: Community Based Alternatives in on Age of Globalization). Yogyakarta: Pustaka Pelajar.

Mandel, Nancy. 1995. Feminist Issues Race, Class and Sexuality. Scarborough, Ontario: Prentice-Hall Canada Inc.

Netting, F. Ellen, Peter M. Kettner and Steven L. McMurtry. 1993. Social Work Macro Practice, New York: Longman.

Soekanto, Soeryono. 2009. Sosiologi Suatu Pengantar. Jakarta: PT. Raja Grafindo Persada.

Suharto, Edi. 2010. Membangun Masyarakat Memberdayakan Rakyat Kajian Strategi Pembangunan Kesejahteraan Sosial dan Pekerjaan Sosial. Bandung: PT. Refika Aditama.

Usman, Sunyoto. 2010. Pembangunan dan Pemberdayaan Masyarakat. Yogyakarta: Pustaka Pelajar. http://www.un.org/ 